International

Medical Society

http://imedicalsociety.org
Vol. 9 No. 166 doi: $10.3823 / 2037$

\section{Social Determinants of Health: Risks and Vulnerability in Adolescence}

ORIGINAL

\title{
Abstract
}

Introduction: Social determinants are understood as the conditions in which people are born, grow, live, work and age, reflecting positively or negatively in their lives. This is seen mainly in adolescents, leaving them susceptible to risks and vulnerabilities that are associated with social inequities, The study of them allows us to identify the influence of these determinants in adolescence. This study aimed to analyze the Social Determinants of Health: Risks and Vulnerabilities in Adolescence through established categories.

Methods: Critical analysis about the social determinants of health and the risks and vulnerabilities in adolescence. There was division into two categories: Risk and Vulnerability in Adolescence and Social Determinants of Health in Adolescence, which identified their most relevant aspects.

Results: The abuse of alcohol and drugs, labor exploitation, violence, unplanned pregnancy and infection by STD/HIV/AIDS were the main risks and vulnerabilities found in adolescence, and those were influenced by social determinants of health.

Conclusion: Health inequities are complex issues that permeate many aspects, both individually and collectively. Although there are policies for the care of adolescent health, there is the need for effective strategies or new empathic and active policies to minimize damages and to provide quality of life as well as the reduction of health inequities. 


\section{Introduction}

Social determinants are understood as the conditions in which people are born, grow, live, work and age, that is, their whole life cycle, encompassing not only the social, but also economic, political, environmental, cultural and individual determinants [1]. It refers to the social conditions of each individual, their characteristics, lifestyle, socioeconomic and demographic conditions, permeated mainly by social inequalities [2].

These are determined according to social class, income distribution, sanitation, epidemiological factors, especially in the forms of illness and deaths from preventable causes, affecting the health and welfare of the individual. Historically, diseases considered of poverty, such as tuberculosis, leprosy, worms (hookworm and schistosomiasis), malaria, Chagas disease, leishmaniosis and trachoma are listed among health inequalities. These diseases are associated with poor hygiene and sanitation, mainly present in the lower socioeconomic populations, whose consequences in health care embody the significance of iniquities $[3,4]$.

Worldwide, concern for the health and social inequities have gained major proportions, and the implementation of measures has achieved great prominence, such as economic development with emphasis on the eradication of extreme poverty, social inclusion, environmental sustainability, good governance, peace and security [1, 2].

It is important to note in this context that health, from the perspective of promotion, is perceived as a positive and participatory concept, being guided by the pursuit of autonomy and equality of individuals and the community and can act on the factors that influence their quality life. Thus, health is understood as a state of complete physical, mental and social well-being, and not merely as the absence of disease $[5,6,7]$.

According to the Law 8080/90 of the Federal Constitution of Brazil, health is a fundamental human right, and the State must provide the essential conditions for this. Housing, food, sanitation, environment, labor, income, education, physical activity, transportation, leisure, access to essential goods and services are considered the main determinants and health conditions. It is noteworthy that health levels represent, in part, the social and economic organization of a country $[8,9]$.

Socioeconomic, cultural and environmental conditions related to the concepts of living conditions, work and economic resources influence the lifestyle and the development of the individual. In this respect, the social determinants that stand out in relation to health are unemployment, violence, hunger, sanitation, underemployment, disordered urbanization and especially housing, since, depending on the location where the individual lives, they become susceptible to vulnerabilities listed in the risk situations $[9,10,11]$.

Moreover, the social determinants have close relationship with the vulnerabilities, especially with adolescents, who, in this period, suffer strong influences that interfere with their identity, leaving them more susceptible to risk situations. These are linked to different experimentations, discoveries, sense of autonomy and desire to become adults, which is common in this phase, as well as the environment in which they live and maintain their social relationships, which can interfere positively or negatively on their development $[12,13,14,15,16]$.

Thus, adolescents are exposed to different forms of vulnerabilities, and this view is supported by the argument that the structural dimension of reality, linked to the needs of individuals, produces different levels of exposure and health problems [11].

In this perspective, this study aimed to carry out a critical analysis about the Social Determinants of Health: Risks and Vulnerabilities in Adolescence, from the categories: Risk and Vulnerability in Adolescence and Social Determinants of Health in Adolescence. Being aware that the social determinants exert strong influences in adolescence, authors deemed appropriate to analyze them from these 
categories, based in existing publications, in order to clarify, through already held discussions, the main influences of social determinants in relation to risks and vulnerabilities in adolescence.

\section{Methods}

This is a critical analysis, carried out from September to December 2015, on Social Determinants of Health: Risks and Vulnerabilities in Adolescence. Authors sought to know the relationship of social determinants of health and the risks and vulnerabilities in adolescence. For a better context and analysis, electronic searches were conducted in the LILACs, SCIELO and MEDLINE, by crossing the descriptors "Social Determinants and Adolescence" and "Risks and Vulnerabilities and Adolescence".

The inclusion criteria for the selection of articles were: being available in full; addressing the descriptors; and being available in Portuguese, English and Spanish languages. It is noteworthy that studies that analyzed other issues not related to social determinants and risks and vulnerabilities in adolescence were excluded. The full texts were analyzed, from which relevant information to the study was drawn.

In the initial search were found 120 articles. After the title reading, 98 were excluded, remaining only 22 articles; among these, 2 were repeated. In total, 20 articles were used (Figure 1). Researchers also consulted information contained in the manuals of the Ministry of Health and the Federal Constitution of Brazil, as well as in websites and reference books during the search.

Then, for further analysis, it was conducted a division in two categories. The first was related to risks and vulnerabilities in adolescence and to situations to which adolescents become more susceptible; the second was related to the principal model of social determinants of health and their influence in adolescence (Figure 1).
Figure 1: Identification and selection of the articles about the Social Determinants in Health: Risks and vulnerabilities in the youth in LILAC'S, SCIELO e MEDILINE databases.

\begin{tabular}{|c|c|}
\hline \multirow{3}{*}{$\begin{array}{l}\text { Databases } \\
\text { LILAC'S: } 74 \\
\text { SCIELO: } 17 \\
\text { MEDLINE: } 29 \\
\text { Total: } 120 \text { articles }\end{array}$} & \multirow{3}{*}{$\begin{array}{l}\text { Excluded articles } \\
\qquad(\mathrm{n}=98)\end{array}$} \\
\hline & \\
\hline & \\
\hline $\begin{array}{l}\text { Selected articles } \\
\qquad(\mathrm{n}=22)\end{array}$ & $\begin{array}{l}\text { Repeted articles } \\
\qquad(\mathrm{n}=2)\end{array}$ \\
\hline$\nabla$ & \\
\hline $\begin{array}{l}\text { Elegible articles } \\
\qquad(n=20)\end{array}$ & \\
\hline
\end{tabular}

\section{Discussion}

\section{Risks and Vulnerability in Adolescence}

Risk is understood as the consequence of exposure to situations that seeks the fulfillment of a wish, which includes the possibility of loss or some physical, material and psychological suffering. In health, this concept refers to the knowledge and experience accumulated about individual or collective risk and relates to actual or potential situations, producing adverse effects that are configured in some type of exposure [17].

These exposure situations refer to risk behaviors that negatively affect the health of the individual. Among these, inappropriate sexual behavior, unprotected sex, infection with an STD/HIV/AIDS, unplanned pregnancy, sedentary lifestyle, eating disorders, abuse of alcohol and/or licit and illicit drugs are the most common in adolescence. [18, 13].

It is noteworthy that, in most cases, these behaviors leave adolescents more susceptible to other vulnerabilities. This concept of vulnerability is related 
to the dimension of reality in which the individual is inserted, in addition to the objective and subjective needs, which are not limited only to individual needs, but also to group needs. It relates to the rights of individuals, social control, autonomy and especially empowerment. It is also understood as the expansion of the concept of susceptibility, as it seeks to understand whether individuals who are more susceptible to diseases are influenced by the external environment or only by individual characteristics [11, 19].

Vulnerability has three important dimensions: individual, social and programmatic. These are interlinked and one influences the other. Individual vulnerability refers to biological, emotional and cognitive aspects of the individual. Social vulnerability is characterized by cultural, social and economic aspects that determine the opportunities to access goods and services, whereas programmatic vulnerability consists of the social resources that are necessary for the protection of the individual in relation to risks and integrity, as well as to physical, social and psychological well-being [20].

This concept is useful for understanding the adolescent process, since it is characterized by a period of physical, psychological and social vulnerability with complex and numerous transformations. The changes in adolescence occur simultaneously, giving rise to emotions and behaviors that make them susceptible to situations of risks and vulnerabilities. Among these situations, the abuse of alcohol and drugs, labor exploitation, violence, unplanned pregnancy and STD infection/HIV/AIDS stand out (Table 1) $[21,22]$.

The use of drugs, whether they are legal or illegal, constitutes one of the main vulnerabilities in adolescence. The access to these substances, in general, is considered easy by adolescents, being acquired by them or by others who pass forward for consumption [23]. Parallel to this, some teenagers enter early in the labor market under conditions of underemployment, exploration, far from schools and a dig-
Table 1. Social Determinants of Health and Vulnerabilities in Adolescence.

\begin{tabular}{|c|c|}
\hline $\begin{array}{l}\text { Social Determinants } \\
\text { of Health }\end{array}$ & $\begin{array}{c}\text { Vulnerabilities in } \\
\text { Adolescence }\end{array}$ \\
\hline \multicolumn{2}{|l|}{ Proximal determinants } \\
\hline \multirow{7}{*}{ Base of the Model } & Violence \\
\hline & Crime \\
\hline & Use of alcohol and drugs \\
\hline & Unplanned pregnancy \\
\hline & Sexual Abuse \\
\hline & Labor exploitation \\
\hline & Prostitution \\
\hline \multicolumn{2}{|l|}{ Underlying layer } \\
\hline \multirow{5}{*}{$\begin{array}{l}\text { Threshold between } \\
\text { individual factors and } \\
\text { social determinants of } \\
\text { health }\end{array}$} & Drug use \\
\hline & Alcohol consumption \\
\hline & Consumption of fats, sweets \\
\hline & Trying new experiences \\
\hline & $\begin{array}{l}\text { Early sexual activity without } \\
\text { protection. }\end{array}$ \\
\hline \multirow{3}{*}{$\begin{array}{l}\text { Intermediary } \\
\text { determinants }\end{array}$} & $\begin{array}{l}\text { Unfavorable socioeconomic } \\
\text { conditions }\end{array}$ \\
\hline & Labor exploitation \\
\hline & $\begin{array}{l}\text { School evasion associated with } \\
\text { failures }\end{array}$ \\
\hline \multicolumn{2}{|l|}{ Macrodeterminants } \\
\hline \multirow{5}{*}{ Last level of the layer } & Socioeconomic conditions \\
\hline & Violence \\
\hline & Labor exploitation \\
\hline & Drug use \\
\hline & Alcohol consumption \\
\hline
\end{tabular}

nified life, involved in organized crime, prostitution, and experiencing various types of violence $[24,25]$.

Today, violence is considered a major concern, both at global and national levels. In Brazil, the number of adolescents between 10 and 19 years of age victims of violence is alarming. Moreover, our country has a high magnitude of victimization among adolescents [26, 27, 28].

As well as violence, adolescent pregnancy is a vulnerability that has gained great prominence and is considered a matter of public health, since this population is more prone to develop problems during 
this period. Among the main problems, hypertensive crises, premature births and anemia are the most common cases in adolescents, besides the risk of death during pregnancy or childbirth, which is something worrying, especially among young people under 15 years old [29].

With regard to infection by STD/HIV/AIDS, this constitutes an important aspect, considering that exposure to STDs is most prevalent during adolescence because of the feeling of invulnerability, common among adolescents. The epidemiological profile of AIDS in Brazil and worldwide shows a higher prevalence of the disease among adolescents and young people, with a higher incidence of infections by HIVIAIDS in the age group from 15 to 24 years in both sexes. In the national scene, in 2014, approximately 734,000 people were living with HIV/ AIDS [24].

The disease shows that low levels of education and other socioeconomic characteristics are associated with increased infections of adolescents and young Brazilians by STD/HIVIAIDS. Although the data show that adolescents have knowledge of STD/HIVIAIDS, there is still an increase of HIV infection, thus showing an increase in the distribution of cases among adolescents [30].

In short, young people are susceptible to situations of risks and vulnerabilities. This fact is mainly related to the feeling of invulnerability, which is common at this stage of life, and to the environment where they are born, grow and develop. It is noteworthy that these situations of risk and vulnerabilities are permeated by social determinants that exert strong influences in the life of the individual $[2,16]$.

\section{Social Determinants of Health in Adolescence}

Social Determinants of Health are defined by the National Commission on Social Determinants of Health (CNDSS) as social, economic, cultural, ethnic/racial, psychological and behavioral factors that influence the occurrence of health inequities and their risk factors in the population. This definition represents a widespread view that the conditions of life and work are related to the individual's health status [9].

Thus, the social determinants refer to the social conditions in which people live and work, or even to the social characteristics within which the life of each person takes place. There are many Social Determinants, however, the most used is the Dahlgren and Whitehead, for explaining the relationship between social factors and individual and collective health. This model is arranged in different concentric layers, according to their level of coverage, from a layer closest to the individual determinants to a more distal layer. It refers to economic, cultural, environmental, living and working conditions, lifestyle, social and community networks, education as determining factors [31].

Individual characteristics such as age, gender and genetic factors have a strong influence on the individual in relation to their potential and health. These are considered proximal determinants and are in the base of the model (Table 2) [32]. In adolescence, these determinants are present and greatly influence the lives of teenagers, as it constitutes a phase full of changes, both in the physical, cognitive, emotional and sexual aspects, which leave them susceptible to certain risk situations and vulnerability $[16,15]$.

In this regard, male adolescents are more prone to violence and crime, as they are more indepen-

Table 2. Social determinants of Health and their influences in youth - Proximal Determinants and Subjacent layers.

\begin{tabular}{|c|c|c|c|}
\hline $\begin{array}{c}\text { Proximal } \\
\text { Determinants }\end{array}$ & Types & $\begin{array}{c}\text { Underlying } \\
\text { layer }\end{array}$ & Types \\
\hline \multirow{4}{*}{$\begin{array}{l}\text { Base of the } \\
\text { Model }\end{array}$} & $\begin{array}{c}\text { Individual } \\
\text { Characteristics }\end{array}$ & \multirow{4}{*}{$\begin{array}{c}\text { Threshold } \\
\text { between } \\
\text { individual } \\
\text { factors } \\
\text { and social } \\
\text { determinants } \\
\text { of health }\end{array}$} & Behaviours \\
\hline & Age & & \multirow{3}{*}{$\begin{array}{l}\text { Individual } \\
\text { lifestyles }\end{array}$} \\
\hline & Gender & & \\
\hline & $\begin{array}{l}\text { Genetic } \\
\text { Factors }\end{array}$ & & \\
\hline
\end{tabular}


dent, being more often exposed to accidents and discussions in traffic with risk of death, and the use of alcohol and drugs, while female adolescents are more susceptible to conditions such as an unplanned pregnancy, sexual abuse, labor exploitation and prostitution [24, 25].

The behaviors and individual lifestyles are on an underlying layer, which are on the threshold between the individual factors and the social determinants of health (Table 2). The lifestyle adopted by an individual influences in their way of living, being based on their behavior and living conditions [33, 32]. Among adolescents, it is common to observe lifestyles related to a number of behaviors and attitudes that harms their health, such as drug use, alcohol intake, consumption of fats and sweets, trying new experiences, early sexual activity without protection. Moreover, the adoption of a lifestyle associated with inappropriate behavior and attitudes puts health at risk, jeopardizing not only the physical state of adolescents, but also the mental state $[34,22]$.

Intermediate determinants are in the next layer, which are the factors related to living and working conditions, as well as access to healthy environments and essential services such as health and education (Table 2) [32]. Adolescents who are in unfavorable socioeconomic conditions enter the labor market early, often in inappropriate situations when compared to other social segments. Labor exploitation is common not only in Brazil but all over the world, with the presence of children and adolescents who work full time and those who are trainees, often having to combine this period of work with school and other activities. It is common to see children and adolescents at street intersections, selling candy, chewing gum, chocolates, and parents are often responsible for such exploitation. Many large industries benefit from this labor exploration and cheap labor of adolescents, depriving them of basic needs, such as leisure, education and health $[35,36]$.
Education and health are important segments for adolescents. The role of the school is crucial in the insertion of adolescents in culture and society, as well as being one of the main opportunities for social inclusion, with proposals and actions to ensure the development of attitudes and skills, enabling adolescents with an expansion of their understanding of the world, and preparing for the job market $[37,38]$.

However, school evasion, associated with failures, is something worrying, given that most teenage students leave school because of repeated failures, need to work to help the family, and also by the lack of incentive to study by the family [39].

Health is a basic need and must be guaranteed, because directly influences adolescent development, as it covers aspects related to the protection, promotion and recovery of health. In order to improve adolescent health it was implemented, among other programs, the Adolescent Health Program, emphasizing the inclusion of individuals in this age group in a health policy. Later, there was a reorientation of this program in Primary Care through the National Policy on the Comprehensive Care for the Health of Adolescents. Currently, there are a number of measures and actions that help adolescent health, such as: Program Health within School; Comprehensive Care to Sexual and Reproductive Health of Adolescents; Adolescents' Handbook, which has basic and essential information; vaccination; and the use of social media and other media by the Ministry of Health. These government actions are the last level of the layer, where the macrodeterminants are presented, which exert strong influences on other layers [40, 41, 42, 43].

The macrodeterminants relate to socioeconomic, cultural and environmental aspects of a society and include supranational determinants, such as the mode of production and consumption of a city, state and country (Table 3) [32]. The adolescent development depends directly on the social structures, which are understood from the economic, so- 
Table 3 Social determinants of Health and their influences in youth - Intermediate determinants and macro determinants.

\begin{tabular}{|c|c|c|c|}
\hline $\begin{array}{l}\text { Intermediary } \\
\text { determinants }\end{array}$ & Types & Macrodeterminants & Types \\
\hline & $\begin{array}{l}\text { Living } \\
\text { conditions }\end{array}$ & \multirow{4}{*}{$\begin{array}{l}\text { Last level of } \\
\text { the layer }\end{array}$} & $\begin{array}{l}\text { Socioeconomic, cultural and environmental } \\
\text { conditions }\end{array}$ \\
\hline & Work & & \multirow{3}{*}{$\begin{array}{c}\text { Supranational determinants, as the mode of } \\
\text { production and consumption of a city, state and } \\
\text { country }\end{array}$} \\
\hline & Access to healthy environments & & \\
\hline & $\begin{array}{l}\text { Essential services such as } \\
\text { health and education }\end{array}$ & & \\
\hline
\end{tabular}

cial, cultural, institutional and political factors, to the specific conditions of each individual or each family. Social and economic conditions are fundamental to determine the health status of a population [28].

The environment in which the adolescent is inserted is considered as one of the key social determinants, because it interferes directly in their construction, training and development. Moreover, major health inequalities happen due to the poor conditions in which people are born, grow, live, work and age. From this perspective, there is the need to give voice to the subjects, for it is through the health promotion principles and values permeated by individual and collective empowerment that people recognize their problems and thus can minimize damage to health $[2,29]$.

\section{Conclusions}

Health inequities are complex issues that permeate many aspects related not only to individual life, but also to social aspects of the individual, which are related to behavior and lifestyle of each. These are extremely important because they influence the development and perception of the world. However, adherence to healthy behaviors is related to socioeconomic and cultural issues and is permeated by social determinants of health.

As adolescence is a troubled phase marked by different sensations, desire for new, inappropriate behaviors and lifestyles, it leaves individuals vulnerable to risk situations, thereby damaging physical, mental and emotional development. The sense of invulnerability, associated with the social determinants of health, has promoted in adolescents behaviors that leave them exposed to numerous risk situations, such as drug use, crime, violence, unplanned pregnancies, infection by STD/HIVIAIDS, labor exploitation and sexual abuse.

These situations cause physical, psychological and emotional distress not only to adolescents, but to family, friends and close relatives. Moreover, some situations experienced by adolescents negatively reverberate throughout their lives, as the consequences of crime, violence, alcohol and drugs, as well as HIVIAIDS virus.

It is noteworthy that this study has limitations, given the fact that it explored only three databases. As contributions of this study, researchers expect to sensitize managers and health professionals because, although there are health policies for the care of adolescent health, there is the need for effective strategies, or even the implementation of new public policies that are more emphatic and active to minimize damage to adolescents, thus providing better quality of life and reduction of health inequities affecting this population.

\section{References}

1. Organização Mundial de Saúde (OMS). Declaração política do Rio sobre determinantes sociais da saúde. Rio de Janeiro, Brasil Out 2011 [citado em 31 dez 2015]; Disponível em: www. who.int/sdhconference/declaration/Rio political declaration portuguese.pdf 
2. Carvalho Al. Determinantes sociais, econômicos e ambientais da saúde. In Fundação Oswaldo Cruz. A saúde no Brasil em 2030 - prospecção estratégica do sistema de saúde brasileiro: população e perfil sanitário [online]. Rio de Janeiro: Fiocruz/ Ipea/Ministério da Saúde/Secretaria de Assuntos Estratégicos da Presidência da República, 2013[citado em 31 dez 2015]; 2(1): 19-38. Available from SciELO Books: http://books.scielo.org/ id/8pmmy/pdf/noronha-9788581100166- 03.pdf

3. Escoda MSQ, Silva DB, Spinelli JAL, Hesio Cordeiro $H$. Seletividade Assistencial Reforça Desigualdades Sociais e produz Iniquidades em Saúde. Revista Espaço para a Saúde. Londrina. Dez 2013[citado em 31 dez 2015]; 13(1): 52-62; Disponível em: http://www.uel.br/revistas/uel/index. php/espacoparasaude/ article/viewFile/10135/pdf_8

4. Instituto de Pesquisa Econômica Aplicada (IPEA). Objetivos de Desenvolvimento do Milênio. Relatório Nacional de Acompanhamento. Brasília, 2014 [citado em 31 dez 2015]; Disponível em: http://www.pnud.org.br/Docs/5 RelatorioNacionalAcompanhamentoODM.pdf

5. Buss PM, Pellegrini Filho A. Determinantes Sociais da Saúde. Editorial, Caderno Saúde Pública, Rio de Janeiro. Set 2006 [citado em 31 de dez 2015]; 22(9): 1772-1773. Disponível em: http://dx.doi.org/10.1590/S0102-311X2006000900001

6. Moretti AC, Almeida V, Westphal MF, Bógus CM. Práticas corporais/atividade física e políticas públicas de promoção da saúde. Saúde soc.[Internet]. Abr/Jun. 2009 [citado em 31 dez 2015]; 18(2): 346-54. Disponível em: http://dx.doi.org/10. 1590/ S0104- 12902009000200017

7. World Health Organization. Milestones in Health Promotion Statements from Global Conferences. Gevena: WHO 2009; [cited 2015 dez 31]. Available from: http://www.who.int/ healthpromotion/Milestones Health Promotion 05022010. pdf

8. Brasil 1988. Constituição da República Federativa do Brasil. Brasília.

9. Buss PM, Pellegrini Filho A. A saúde e seus determinantes sociais. Physis: Revista de Saúde Coletiva, Rio de Janeiro, 2007 [citado em 31 de dez 2015]; 17(1): 7-93. Disponível em: http:// www.scielo.br/pdf/physis/v17n1/v17n1a06.pdf

10. Oliveira MJI, Santo EE. A Relação entre os Determinantes Sociais da Saúde e a Questão Social. Caderno Saúde e Desenvolvimento. Jan/Jun 2013 [citado em 31 dez 2015]; 2(2). Disponível em: http://www.grupouninter.com.br/revistasaude/index.php/ cadernosaudedesenvolvimento/article/view/219/102

11. GuimarãesMCS, NovaesSC.Autonomiareduzidaevulnerabilidade: liberdade de decisão, diferença e desigualdade. Rev Bioética. 2010; [citado em 31 dez 2015]; 7(1): 21-4. Disponível em: http://revistabioetica.cfm.org.br/index.php/revista bioetica/ article/view/288/427

12. Mendes, EV. As redes de atenção à saúde. Ciência \& Saúde Coletiva, Rio de Janeiro. Aug 2010 [citado em 31 dez 2015]; 15(5): 2297-2305. Available from: http://dx.doi.org/10.1590/ S1413-81232010000500005

13. Taquette SR, Vilhen MM. Adolescência, gênero e saúde. Revista Adolescência \& Saúde, Rio de Janeiro. Abr. 2006 [citado em 31 dez 2015] 3(2): 6-9. Disponível em: http://www. adolescenciaesaude.com/detalhe artigo.asp?id=139
14. Hockenberry MJ, Wong DL. Fundamentos de enfermagem pediátrica. $8^{\circ} \mathrm{ed}$. Rio de Janeiro. Elsevier, 2011

15. Wong DL. Enfermagem Pediátrica: Elementos essenciais à Intervenção efetiva. 8. ed. Rio de Janeiro: Elsevier, 2011

16. Carmo DRP, Padoin SMM, Paula CC, Souza IEO. Adolescente que cumpre medida socioeducativa: modos de ser no cotidiano e possibilidades para enfermagem. Rev Gaúcha Enferm. [Online] Porto Alegre. Set. 201[citado em 31 dez 2015]; 32(3): 472-478. Disponível em: http://dx.doi.org/10.1590/S1983$\underline{14472011000300006}$

17. Schenker M, Minayo MCS. Fatores de risco e de proteção para o uso de drogas na adolescência. Ciência \& Saúde Coletiva. 2005 [citado em 31 dez 2015]; 10(3): 707- 717. Disponível em: http:// www.scielo.br/pdf/csc/v10n3/a27v10n3.pdf

18. Jesus FB, Lima FCA, Martins CBG, Matos KF, Souza SPS. Vulnerabilidade na adolescência: a experiência e expressão do adolescente. Revista Gaúcha de Enfermagem [Online] Porto Alegre. Jun. 2011[citado em 31 dez 2015]; 32(2): 359-367. Disponível em: http://dx.doi.org/10.1590/S198314472011000200021

19. Ayres SJRCM, Calazans GJ, Saletti F, Haraldo C, França JR. Risco, vulnerabilidade e práticas de prevenção e promoção da saúde. In: Campos, GWS; Minayo, MCS; Akerman, M; Drumond, MJr; Carvalho, YM. Organizadores. Tratado de saúde coletiva. Rio de Janeiro (RJ): Fiocruz; 2006. p. 375-417.

20. Rodrigues NO, Ner AL. Vulnerabilidade social, individual e programática em idosos da comunidade: dados do estudo FIBRA, Campinas, SP, Brasil. Ciência \& Saúde Coletiva, Rio de Janeiro. 2012 [citado em 31 dez 2015]; 17(8): 2129-2139. Disponível em: http://dx.doi.org/10.1590/\$1413-81232012000800023

21. Unicef. O direito de ser adolescente: Oportunidade para reduzir vulnerabilidades e superar desigualdades / Fundo das Nações Unidas para a Infância. Brasília, DF, 2011 [citado em 31 dez 2015]. Disponível em: http://www.unicef.org/brazil/pt/br sabrep11.pdf

22. Davim RMB, Germano RM, Menezes RMV, Carlos DJD. Adolescente/Adolescência: revisão teórica sobre uma fase crítica da vida. Rev Rene. 2009 [citado em 31 dez 2015]; 10(2): 131-140. Disponível em: http://www.revistarene.ufc.br/revista/ index.php/revista/article/view/500/pdf

23. Zeitoune RCG, Silveira HS, Domingos AM, Maia AC. O conhecimento de adolescentes sobre drogas lícitas e ilícitas: uma contribuição para a enfermagem comunitária. Esc. Anna Nery. Rio de Janeiro. Mar 2012 [citado em 31 dez 2015]; 16(1): 57-63. Disponível em: http://dx.doi.org/10.1590/S141481452012000100008

24. Ministério da Saúde - Secretaria de Vigilância em Saúde Departamento de DST, Aids e Hepatites Virais. Brasil, 2014.

25. Reis DC, Almeida TAC, Miranda MM, Alves RH, Madeira AMF. Vulnerabilidades à saúde na adolescência: condições socioeconômicas, redes sociais, drogas e violência. Rev. LatinoAm. Enfermagem. 2013 [citado em 31 dez 2015]; 21(2). Disponível em: http://dx.doi.org/10.1590/S0104-116920130002000

26. Waiselfisz JJ. Mapa da Violência 2015: Homicídio de mulheres no Brasil. Fonte Diagramação: All Type Assessoria Editorial Ltda, 2015[citado em 31 dez 2015]; Disponível em: www. mapadaviolencia.org 
27. Malta DC, Mascarenhas MDM, Porto DL, Barreto SM, Morais Neto, OL. Exposição ao álcool entre escolares e fatores associados. Revista de Saúde Pública, São Paulo. Jan./Fev. 2014 [citado em 31 dez 2015]; 48(1): 52 -62. Disponível em: http://dx.doi.org/10.1590/500348910.2014048004563

28. Ministério da Saúde. Secretaria de Atenção à Saúde. Departamento de Ações Programáticas Estratégicas. Orientações básicas de atenção integral à saúde de adolescentes nas escolas e unidades básicas de saúde. Brasília: Editora do Ministério da Saúde, 2013.

29. Mota RM. História oral de adolescentes grávidas em situação de violência doméstica - Salvador, 2012. Universidade Federal da Bahia. Escola de Enfermagem, 2012 [citado em 31 dez 2015]. Disponível em: https://repositorio.ufba.br/ri/handle/ri/11161

30. Campos CG, Estima SL, Santos VS, Lazzarotto, AR. A Vulnerabilidade ao HIV em Adolescentes: Estudo Retrospectivo em um Centro de Testagem e Aconselhamento. Rev Min Enferm. Abr/Jun 2014 [citado em 31 dez 2015]; 18(2): 310-314. Disponível em: http://www.reme.org.br/artigo/detalhes/9297

31. Mendes EV. O cuidado das condições crônicas na atenção primária à saúde: o imperativo da consolidação da estratégia da saúde da família. / Eugênio Vilaça Mendes. Brasília: Organização Pan-Americana da Saúde, 2012 [citado em 31 dez 2015]; Disponível em: http://bvsms.saude.gov.br/bvs/publicacoes/ cuidado condicoes atencao primaria saude.pdf

32. Cndss Comissão Nacional sobre Determinantes Sociais da Saúde. As causas sociais das iniquidades em saúde no Brasil. Rio de Janeiro: Editora Fiocruz, 2008 [citado em 31 dez 2015]. Disponível em: http://bvsms.saude.gov.br/bvs/publicacoes/ causas_sociais_iniquidades.pdf

33. Nahas MV. Atividade física, saúde e qualidade de vida: conceitos e sugestões para um estilo de vida ativo. 5. edição. Londrina: Miograf, 2010.

34. Santos ARM, Silva EAPC, Silva PPC, Cartaxo HGO, Freitas CMSM. Estilo de vida na adolescência: O Envolvimento Religioso atuando nos Comportamentos de Risco à Saúde. Pensar a Prática, Goiânia. Jan./Mar. 2014 [citado em 31 dez 2015]; 17(1): 01-294. Disponível em: https://www.revistas.ufg.br/index.php?j ournal=fef\&page $=$ article\&op=view\&path $\% 5 B 5 D=18741$

35. Silva JF, Belusso SL, Ilha AS. Algumas considerações sobre a Exploração do Trabalho Infantil. Congresso de la asociacion latino-americana de sociologia rural (ALASRU), Equador, 2009 [citado em 31 dez 2015]. Disponível em: https://www. researchgate.net/publication/242461279

36. Raposo, C. A Política de Atenção Integral à Saúde do Adolescente e Jovem: uma perspectiva de garantia de direito à saúde? Revista da Faculdade de Serviço Social da Universidade do Estado do Rio de Janeiro. Jul 2009 [citado em 31 dez 2015]; 6(23) - Disponível em: http://www.e-publicacoes.ueri.br/index. php/revistaempauta/article/view/450/548

37. Padovani $\mathrm{M}$, Ristum M. A escola e a construção da identidade de adolescentes autores de ato infracional. Revista entre Ideias, Salvador. Jul./Dez. 2013 [citado em 31 dez 2015]; 2(1): 151 -167. Disponível em: http://www.portalseer.ufba.br/index.php/ entreideias/article/view/7672/6683
38. Facci MGD. A escola é para poucos? A positividade da escola no desenvolvimento psicológico dos alunos em uma visão Vygotskyana. Psicologia Política. 2010 [citado em 31 dez 2015]; 10(20): 297-310. Disponível em: http://pepsic.bvsalud.org/ scielo.php?script=sci arttext\&pid=\$1519549X2010000200010 \&lng=pt\&nrm=iso

39. Inep-Instituto Nacional de Estudos e Pesquisas Educacionais Anísio Teixeira. Diretoria de Tratamento e disseminação de informações Educação no Brasil, 2011[citado em 31 dez 2015]. Disponível em: http://www.todospelaeducacao.org.br/ educacao-no- brasil

40. Jager ME, Batista FA, Santos CMPSS, Dias ACG. O Adolescente no contexto da Saúde Pública Brasileira: Reflexões sobre o Prosad. Psicologia em Estudo, Maringá. Abr./Jun. 2014 [citado em 31 dez 2015]; 19(2): 211-221. Disponível em: http://dx.doi. org/10. 1590/1413-737221567004

41. Ministério da Saúde. Secretaria de Atenção em Saúde. Departamento de Ações Programáticas Estratégicas. Diretrizes nacionais para a atenção integral à saúde de adolescentes e jovens na promoção, proteção e recuperação da saúde. Brasília: Ministério da Saúde, 2010.

42. Lyra J, Medrado B, Oliveira AR, Sobrinho A. Juventude, mobilização social e saúde: Interlocuções com políticas públicas. Recife: Instituto PAPAI/MAB/Canto Jovem, 2010, $2^{\text {a }}$ ed. [citado em 31 dez 2015]; pp. 109-130. Disponível em: http://www. unfpa.org.br/Arquivos/ena.pdf

43. Bastos LF, Leite SS, Martins MC, Pagliuca LMF, Rebouças CBA. National Polyce of Health Promotion: a Vision about Operation Axes. Inter Archv Med [Interne] 2016 [ cited em 07 jul 2016]. Disponível em: http://www.intarchmed.com/ 